\title{
Kaspar Villadsen
}

\section{Filantropiens genkomst \\ - Medborgerskab, fællesskab og frihed under ombrydning?}

1800-tallets filantropiske principper for fattighjælp er ved at blive genopdaget. Dette medforer ikke blot en transformation af socialpolitikken og det sociale arbejde. Genopdagelsen indikerer også at, vores forestillinger om medborgerskab, fællesskab og frihed er under transformation. Artiklen præsenterer nogle hovedlinier fra den kommende bog Det sociale arbejdes genealogi - kampen for at gøre fattige og udstødte til frie mennesker. 
$\mathrm{D}$ et sociale arbejdes diskurs har fået nye begreber. Fra utallige sider lyder de samme slagord: "Man skal møde mennesket, som det er", "hjælp skal være hjælp til selvhjælp" og "fattigdommen er åndelig snarere end materiel“. Parolerne kræver ikke blot en lettere omstrukturering af det sociale arbejdes metoder. Argumentet i denne arti$\mathrm{kel}^{1}$ vil derimod være, at de populære principper sætter ganske meget på spil. For det første, at udbredelsen af de nye magiske trylleformularer indikerer mere grundlæggende tranformationer i selve det sociale arbejdes epistemologi - altså i måden, hvorpå et socialt problem overhovedet kan genkendes som et socialt problem, og i måden hvorpå en social klient overhovedet kan genkendes som klient. Og for det andet, at disse transformationer peger mod et igangværende opbrud i vores forestillinger om, hvad medborgerskab, fællesskab og frihed er for nogle størrelse.

Det sociale arbejdes får sin særlige karakter i kraft af de forskellige vidensformer, som det trækker på og kombinerer. Jacques Donzelot 1979 hævder, at socialt arbejde skal begribes med udgangspunkt i dets 3 konstituerende dimensioner: Det juridiske, det psykologiske og det pædagogiske. Disse vidensformer rummer meget forskellige forestillinger om, hvad klienten er for en størrelse, og hvad der er målet med socialt arbejde. Den juridiske dimension iagttager klienten som rettighedssubjekt og forsøger at fastsætte lovbestemte relationer mellem borgeren og socialforvaltningen. Spørgsmålet er, hvorvidt der er lovhjemmel til diverse interventioner, og hvordan klientens rettigheder over for staten sikres. Den psykologiske dimension iagttager klienten som $p s y$ kologisk væsen og forsøger at forklare hans adfærd og problemer ud fra diagnosticérbare lidelser og psykiske strukturer. Spørgsmålet er, hvordan man kan styrke klientens evne til at klare tilværelsens udfordringer på trods af diverse psykiske problemer. Endelig iagttager den $p x-$ dagogiske dimension klienten som et socialt, ansvarshavende subjekt. Spørgsmålet er her, hvilke sociale kompetencer den enkelte skal være i besiddelse af for at begå sig i samfundsfællesskabet, og hvorvidt den enkelte har vilje til i sin livsførelse at honorere fællesskabets normer. Denne dimension betoner medborgerskabets moralske karakter. I konkrete sociale indsatser som $\mathrm{fx}$ aktivering eller fjernelse af et barn spiller de 3 dimensioner typisk sammen, idet der kan være spørgsmål, der både involverer juridisk, psykologisk og pædagogisk viden. Det er oplagt, at de forskellige dimensioners betydning i det sociale arbejde kan variere - og har varieret - over tid.

I det følgende vil jeg i særlig grad sætte fokus på den pædagogiske dimension, idet jeg hævder, at denne dimension er på fremmarch på bekostning af det sociale arbejdes to øvrige dimensioner. Jeg hævder endvidere, at det sociale arbejdes pædagogiserende og moraliserende elementer står i forbindelse med 1800tallets filantropiske arbejde - et velgørenhedsarbejde, der netop havde som sit hovedsigte at styrke den fattiges erkendelse af sin moralske forpligtelse over for samfundsfællesskabet. Som led i en diskussion af, hvor det sociale arbejde aktuelt er på vej hen, bliver en undersøgelse af denne "pædagogisk-filantropiske dimension" og dens historiske rødder derfor relevant.

\section{Historisk sociologi og genealogi}

Hvorfor grave tilbage i det sociale arbejdes historie? Historisk interesserede tænkere som Max Weber, Norbert Elias og Michel Foucault har hver især givet deres bud på, hvad en kritisk historisk sociologi bør bestå i. I Den protestantiske etik 
og kapitalismens ånd viste Weber 1995 bl.a., hvordan kapitalismens ethos dens særlige mål-middel rationalitet og krav om "økonomisk livsførelse" - var forbundet med fortidige calvinistiske forestillinger om puritanisme og askese. Han viste, hvordan førmoderne, irationelle forestillinger syntes at blive videreført i det, der ellers blev betragtet som en moderne rationalitet. En lignende strategi optræder i Foucaults genealogier, der også viser, hvordan moderniteten rummer kontinuiteter med dens "uoplyste" fortid, bl.a. ved at moralske skel mellem godt og ondt videreføres i videnskabernes skel mellem normalitet og patologi. Eller mere præcist: Når oplysningsfortællingen beskriver historien gennem brud, der lægger fortidens påståede barbari og irationelle forestillinger bag sig, eftersøger Foucault kontinuitet. Og omvendt: når historien beskrives som en logisk, evolutionær proces, påviser Foucault de brud, kampe og udgrænsninger, som modernitetens vidensformer er resultat af (Villadsen 2002:85). På forskellige vis benytter Weber og Foucault sig begge af et analytisk greb, der fremviser moderne rationalitetsformers historiske kontingens ved at vise deres forbundethed med det førmoderne og "irationelle". I det følgende vil denne analysestrategi blive søgt overført på det moderne sociale arbejde, idet der netop sættes fokus på det sociale arbejdes forbindelse til forlængst glemte vidensformer og praksisser.

Det sociale arbejde kan betragtes som et særlig socialt system, der strukturer handling - såvel handling på andre som handling på én selv. Ligesom det gælder for Elias' historiske figurationer (Elias 1994:214) eller for Foucaults dispositiver, er der tale om en social anordning, der kræver særlige typer styring og selvstyring af de involverede, hvis de vil være legitime og kompetente agenter. Man kan også sige, at det sociale arbejde som hi-

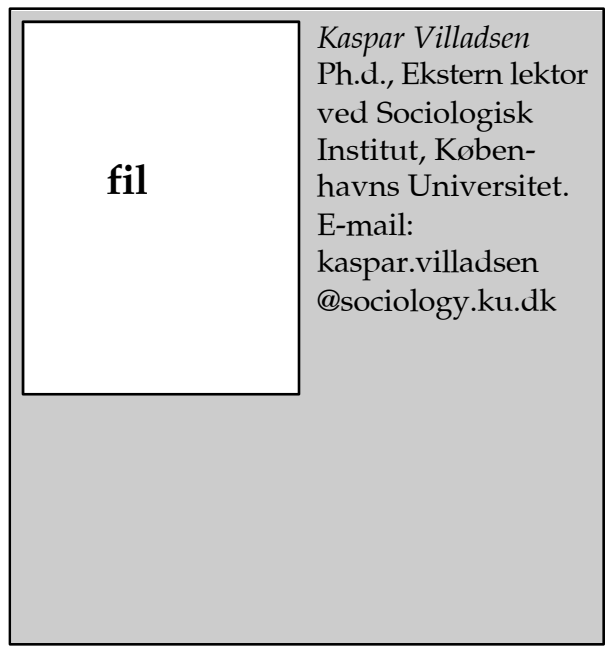

storisk anordning disponerer handlinger og selv-refleksion i en bestemt retning. Det sociale arbejdes diskurs, teknologier og institutioner virker sammen for at fremelske bestemte subjekter - ikke blot $\mathrm{i}$ "de styrede" (klienterne), men også i "de styrende" (socialarbejderne). Foucaults udgangspunkt er nu, at en social anordning kun kan eksistere i kraft af de historiske elementer, som den viderefører og knytter sammen: vidensformer, institutioner og praktiske teknologier (Foucault 1991:76). En interessant, men ofte overset, pointe er i denne forbindelse, at historiske elementer kan blive re-aktiveret $\mathrm{i}$ nutidig anordninger og her tjene nye strategiske funktioner. I en analyse af det sociale arbejde som anordning må man derfor forfølge de forskellige elementers ophav via genealogisk analyse. Antallet af elementer, der kan forfølges, vil være uoverkommeligt stort, så der må træffes nogle valg om, hvilke elementer der skal udvælges til analysen. I nærværende sammenhæng er det som sagt den filantropiske dimension i det sociale arbejde, som den genealogiske analyse vil koncentrere sig om. 
1800-tallets brud med

\section{patriarkalsk fattigforvaltning}

Man kan med god ret hævde, at det moderne sociale arbejde fødes i sidste halvdel af 1800-tallet. Philp (1979) argumenterer ligefrem for, at det sociale arbejdes "diskursive formationsregler" grundlægges i denne periode. Såvel den statslige fattigadministration som diverse kirkelige og frivillige foreninger formulerer her et opgør med den hidtidige paternalistiske fattigpolitik - et opgør, der må betragtes som afgørende for etableringen af moderne socialpolitik og det moderne sociale arbejde. Opgøret rummer 3 elementer: 1) en problematisering af fattigvæsenets tvangsanvendelse, 2) en rekonstruktion af den fattiges essentielle karakter, og 3) et krav om øget differentiering mellem forskellige typer fattige. Lad os se på dem hver især.

1800-tallets fattigpolitik udvikles i høj grad som et svar på styringsproblemer i den hidtidige fattigforvaltning. Dens foretrukne mirakelmiddel, arbejdsanstalten, havde vist sig at være økonomisk omkostningsfuld, og der formuleres en stigende bekymring over de effekter, som den synes at have på fattiglemmerne. Især rejses spørgsmålet om, hvorvidt tvang er et hensigtsmæssigt middel til at skabe det individ, som man nu ønsker at fremelske. Flere og flere rejser spørgsmålet: Skaber tvangsarbejdsanstalten ikke snarere en uselvstændig og "tvungen" arbejder end en selvstændig og driftig arbejder? Skematisk kan man sige, at der i sammenligning med 1700-tallets fattigpolitik skal skabes et nyt subjekt. Beskeden til den fattige er ikke længere: "Bliv på din plads og vent på min ordre!" Det drejer sig nu om at fremelske en uafhængig arbejder, der træffer frie, men ansvarlige valg. Ansvarlighed og uafhængighed bliver det, som enhver indsats må søge at realisere, og til dette formål opfattes formynderisk tvangsarbejde mere og mere som kontraproduktivt. Først og fremmest hævdes det, at tvangen udrydder selvfølelsen hos fattiglemmerne og hermed umuliggør, at de senere kommer til at føre en tilværelse som uafhængige arbejdere. I stedet for tvangsmæssig indespærring bør man støtte folk, før de falder så dybt, at anstalten er den eneste mulighed. Fx taler Provst Bendix for at indføre "frihedens ånd" i fattigforvaltningen og erstatte tvangen med en håndsrækning mod selvstændighed:

Det er jo en Tvang, hvordan man dreier og vender det, naar enhver Mand, der i Øieblikket ikke kan ernære sig selv, skal pakkes ind i en saadan Anstalt. (...) Den almindelige Virkning af en Arbeidsanstalt er, at man udrydder den Selvfølelse, som er den nødvendigste Betingelse, for at et Menneske skal kunne gaae gjennem Livet med Følelsen af, at han er stærk nok til at staae paa egne Been (Bruun et al. 1866:42).

Den stærke bekymring for tabet af selvstændighed, som fattiganstalterne påstås at pådrage de indsatte, udgør et væsentligt brud med 1700-tallets fattigpolitik. Her anvendte man uden tøven diverse forantaltninger, der skulle tvinge fattiglemmerne til et liv i disciplin, arbejdsomhed, sædelighed mv., og man håbede så, at de ville fortsætte denne påtvungne livsførelse uden for anstalterne. Nu anklages den samme tvang for at rumme en overhængende risiko for at nedbryde den oprindelige virkelyst og selvstændighed, som antages at besjæle den fattige arbejder. Frihedstrang og virkelyst er altså ikke noget, der skal påføres den fattige arbejder. I stedet må man skabe rammer, der virker befordrende for disse kvaliteters naturlige udfoldelse. I fattigforvaltningen får den nye bekymring som konse- 
kvens, at visse gamle forsorgs- og støttesystemer bliver afviklet. Det gælder for den såkaldte arbejdslægd, borttingning og hjemstavnsretten. Det fælles problem for disse forsørgelsesmåder er, at de forhindrer etableringen af frie kontraktlige relationer mellem arbejdsgiver og arbejdstager. Teologen Ole Sandberg siger fx om arbejdslægden:

\section{Man har der fundet, at denne Maade [arbejdslægd, K.V.] at ord- ne Arbeidet paa først og fremmest ophæver det Forhold mellem Ar- beidsherre og Arbejder, som en fri Kontrakt og et frit Valg i alminde- lighed medføre (Sandberg 1869: 107).}

Problematiseringen af fattigvæsenets skadevirkninger i forhold til målet om at skabe et selv-ansvarligt individ, der kan gå ud på markedet og indgå kontrakter, er det første element i opgøret med 1700tallets fattigpolitik. Man må skabe et stabilt subjekt, som er "til at regne med".

For det andet - og nært knyttet til ovenstående - sker der en rekonstruktion af den fattiges essentielle karakter: i stedet for at rumme et iboende kim til fordærvelse antages den fattige nu at rumme en iboende vilje og ansvarlighed, som man kan tale til og søge at få frem. I 1700tallets fattiglitteratur og op gennem 1800tallet blev den fattige fremstillet som et væsen, der var grundlæggende anderledes end den driftige og besiddende borger. Den fattige var af naturen doven, uambitiøs, løgnagtig og usædelig. Han rummede i sit indre et iboende kim til fordærvelse, som konstant truede med at bryde ud i fuldt flor, hvis det ikke blev holdt $i$ ave gennem påvirkningen fra en vis tvang, flittigt arbejde og åndelig dannelse. Således kan præsten Carl Wilhelm Brodersen i 1834 hævde, at det er nødvendigt at: ...søge at trænge ind i det inderste Menneske og see, om ikke der maaske en Spire ligger skjult, af hvilken der udviklede sig en saadan Leveviis, der nødvendigvis havde Forarmelsen tilfølge (Brodersen 1834:15).

Diverse skribenter, velgørere og fattigforvaltere forskrækkes fortsat over de fattiges iøjnefaldende elendighed og fordærvelige livsførelse. Det påpeges, at der i visse bykvarterer lever mennesker, hvis normer og hele leveform er fundamentalt forskellig fra middelstandens. Nogle dagblade ansætter ligefrem føljetonskribenter til at rejse rundt i de fremmede dele af byen for at forsyne deres læsere med øjenvidne-beretninger. Fx skriver Herman Bang i 1881:

Der er i Samfundet fremmede og
besynderlige Egne. Egne, hvor Fo-
restillingerne ikke ere vore, Love-
ne er andre, deres Liv er et andet
et vort. De dyrke ikke de samme
Guder, de forstaa os ikke, vi ikke
dem; Ordene, hvori de tale, ere de
samme, men deres Betydning er
en anden (Bang 1881:5).

Men det afgørende er, at fordærvelsen ikke længere opfattes som en iboende eller uoverstigelig del af disse mennesker. I sidste halvdel af 1800-tallet understreges det derimod i stigende grad, at der bag selv den mest forfærdende elendighed gemmer sig et menneske, der er ligesom du og jeg. Rekonstruktionen af den fattige giver mulighed for en strategi om at "opløfte" de fattige til respektable borgere - vi ser her forløberen for eftertidens begreb om integration.

For det tredje stilles der krav om en øget differentiering mellem forskellige typer fattige. Alt for længe har man behandlet de fattige som om, de var en ens- 
artet gruppe, lyder det. Herved har man overset, at de fattige består af meget forskellige mennesker, hvis fattigdom har meget forskellige årsager. Ikke mindst er de fattige præget af vidt forskellige grader af moralitet, og det må enhver indsats afpasses efter. Der gøres utallige forsøg på at skelne mellem dem, der endnu kan hjælpes på fode, og dem, der er gået $\mathrm{i}$ absolut moralsk fordærv. Nogle taler for at bruge ydre tegn i hjemmet, som indikator på den indre fordærvelse: fremviser køkkenet, klæderne og børnene vilje til at opretholde renhed, værdighed og økonomisk husførelse? Udgangspunktet er her, at det selv i den dybeste Armod er muligt at bevare en slags "anstændig renlighed". Andre taler om en fordærvelsesproces, hvor varigheden af den fordærvede tilstand anvendes som kriterie for et fuldstændigt fordærv. En skribent ${ }^{2}$ hævder ligefrem, at der ikke længere er nogen chance for oprejsning, når den fattige er fyldt 36 år (Stuckenberg 1869:36). Det, der er grundlæggende for grænsedragningerne, er imidlertid, hvorvidt den pågældende viser indikation på vilje eller ej. Er der stadig en vilje til selvoprejsning, som kan vækkes, eller er den fattige viljeløs og hermed fortabt?

Filantropister og andre velgørere formulerer princippet om, at "man skal rejse dem, der kan rejses". Det betyder, at hjælpen skal forbeholdes dem, der fremviser god vilje, således at indsatsen ikke spildes på dem, der er fortabte. Man forsøger at sortere mellem dem, der skal have hjælp af "det milde fattigvæsen" - dvs. private, kirkelige og filantropiske foreninger - på den ene side, og dem, der skal indsættes i det "strenge" offentlige fattigvæsen, på den anden. Således ser Christianshavns understøttelsesforening det som sin hovedopgave at standse nogle af de mange, som ellers ville søge det offentlige fattigvæsen. Formanden Pastor Munck skriver:
Dertil maa det bringes, at den Deel af Fattigdommen, som kan reises og vil reises, finder en tilstrækkelig Støtte og Tilflugt hos den private Velgørenhed, saa at det offentlige Fattigvæsen kun lidt efter lidt faaer med dem at gjøre, som ikke ville reise sig selv og derfor heller ikke kunne reises (Munck et al. 1867:78).

De fremvoksende filantropiske foreninger anlægger et pragmatisk princip, der indebærer, at hjælpen skal ydes dér, hvor den er mest virksom. Dette betyder, at indsatsen skal koncentreres om de familier, der endnu "kan rejses". Derfor får de såkaldte fattigundersøgere til opgave at sortere mellem de familier, der kan hjælpes til at opretholde deres autonomi, og dem, der må optages i det offentlige fattigvæsen. Det nyopfundne iagttagelsesperspektiv, der forsøger at dømme vilje eller ikke-vilje, skal vise sig at blive absolut afgørende for eftertidens sociale arbejde.

\section{Filantropiens fællesskabsfore- stilling og tekniske kreativitet}

Det bliver de filantropiske foreninger, der blomstrer op i sidste halvdel af 1800-tallet, som først og fremmest formulerer den moderne fattigdiskurs. Inden for denne diskurs sker der ikke blot en rekonstruktion af den fattige person og hans karakter. Der operereres også med en ny fællesskabsforestilling. Filantropien befinder sig her mellem to modstridende politiske positioner: på den ene side står socialisterne, der vil løse fattigdomsproblemet gennem kollektivisering. Staten må tage ansvaret via lovgivning eller ved at kollektivisere produktionsmidlerne. Og $p a ̊$ den anden side står liberalister og konservative, der ønsker at overlade problemerne til markedskræfterne og den frivillige godgørenhed. Statslig intervention vil ikke blot hindre de frie markedskræfters 
velfærdsskabende funktioner, men også ødelægge "de kærlige bånd", der binder samfundsklasserne sammen. Filantropiens løsning består i at skabe et fællesskab, der hverken styres af staten eller markedet - et moralsk fællesskab. Et fællesskab, hvor individerne er bundet sammen i kraft af deres fælles moral og deres følelse af forpligtelse over for dette fællesskab. Nøjagtigt som Durkheim, understreger filantropisterne, at liberale kontrakter ikke kan fungere uden et understøttende sæt af fælles normer og forpligtelser - dvs. kontraktens "ikke-kontraktlige grundlag" (Durkheim:2000).

Men hvordan skabe et sådant moralsk fællesskab? Det er oplagt, at det næppe kan genereres gennem statslig styring og intervention. De socialt sammenbindende normer må derimod udlæses og udgå fra det civile samfund selv. Indsatsen må bestå $i$ at stimulere disse normer og befordre deres konkrete manifestation i de fattiges hverdagsliv. Det er her filantropien får sin store betydning. De filantropiske foreninger søger netop at udføre en indsats, der moraliserer og integrerer de fattige via det civile samfunds egne fællesskaber, og hermed friholder staten fra en opgave, som den per definition er uegnet til.

Blikket retter sig især mod to sådanne fællesskaber: dels familien og dels foreningsfællesskabet. Jeg vil i denne sammenhæng koncentrere mig om indsatsen rettet mod familien ${ }^{3}$. Mange peger på, at industrialiseringen og tilvandringen til byerne synes at medføre moralsk opløsning og forstærkede klassemodsætninger, der i faretruende grad truer med at splitte samfundet fra hinanden. Hvem skal danne de masser af unge byarbejdere, der tidligere havde været underlagt landbofællesskabets, storfamiliens eller mesterens moralske påvirkning og overvågning? Alle - lige fra Arbejderbevægelsens Louis Pio til
Indre Missions Harald Stein - peger på familien som middel mod normernes opløsning. Familien fremstilles som det rum, hvori de gode moralske normer ikke blot kan opretholdes, men hvorfra de også kan udbredes til det øvrige samfund. Sunde borgere og hermed det sunde samfund udgår fra hjemmet, hævdes det (Johansen 1883).

Det bliver først og fremmest de filantropiske foreningers fattigundersøgere, der får til opgave at værne om og bistå den fattige familie, således at den kan opretholde sin moralske og økonomiske autonomi. Dette skyldes utvivlsomt, at filantropien er et middel, der synes i god overenstemmelse med periodens liberale statsopfattelse. De filantropiske foreningers styrke er, at de er i stand til på en meget konkret facon at omdirigere de krav om handling, der rettes mod staten, til det fattige hjem. Til de fattige lyder budskabet: fremfor at stille vidtløftige fordringer til staten og samfundet, så se at få orden på forholdene i dit hjem og din egen levemåde! Det understreges, at der ikke kan skabes forandringer mod et bedre samfund, førend den enkelte har lært at udøve fromhed, arbejdsomhed og nøjsomhed i det daglige:

Det er nu éngang en Grundlov i Guds Rige, at vi aldrig blive satte over mere, aldrig vokse til at betros det større, uden at vi først lærte at være tro i det mindste. (...) og altid sker Væksten saaledes ved Troskab og Lydighed i det smaa, i det daglige, - aldrig, aldrig ved aandelige Himmelfagter, i ét Slag, paa engang! (Hoff 1881:16).

I det filantropiske arbejde kommer begrebet om "det gode hjem" således til at fungere som en støttepille for den gældende sociale orden - et centralt referencepunkt for tilbagevisning af fundamentale kri- 
tikker af samfundsindretningen. At opnå et bedre liv kræver først og fremmest den enkeltes tålmodige arbejde med sig selv og kan ikke realiseres gennem sværmerier for en samfundsmæssig revolution. Med andre ord: frem for at forfølge vidtløftige ideer om store samfundsforandringer stiller filantropister og andre velgørere krav til deres modtagere om at udøve, hvad man med Foucault kan kalde "selvets arbejde på selvet" inden for hjemmets ramme:

Det er jo ikke Hjemmets Form, der gør Sagen klar, det er os selv, det gælder, ja, som vi ere, saaledes bliver vort Hjem. Altsaa: det er paa os selv vi maa rette vor Stræben, vor Bøn (Hoff 1881:37).

Den form for hjælp, som filantropien yder de fattige familier, har en omkostningsorienteret og pragmatisk karakter. Den er omkostningsorienteret, fordi det konstant overvejes, hvordan hjælpen kan indrettes for med mindst mulig indsats at opnå de mest vidtgående resultater. Ikke mindst er det afgørende at producere effekter, der ikke blot virker nu og her, men rækker langt ind i fremtiden. Derfor anvender filantropien teknikker, der skal installere de moralske forpligtelser i de fattige og dermed virke disponerende på deres fremtidige handlinger. Der indgås aftaler og kontrakter, der gennemføres overvågning af husførelsen, der ydes pædagogisk rådgivning, og til tider må der uddeles strenge formaninger. Filantropiens hjælpevirksomhed repræsenterer en liberal form for magtudøvelse, idet den søger at forme formelt frie individers handlinger - herunder ikke mindst de fremtidige handlinger. Hjælpen er desuden pragmatisk. Den traditionelle almissegerning blev anskuet som en handling, der havde en værdi i sig selv uanset dens resultater: almissen vækker på én gang barmhjertigheden i giveren og den ydmyge taknemmelighed i modtageren. Gerningen realiserer på denne måde begge parters grundlæggende menneskelighed og bringer dem tættere på Gud. I modsætning hertil er filantropiens hjælpevirksomhed drevet af mere pragmatiske mål-middel overvejelser: "Giv hjælpen til kvinden fremfor manden". Hun er ansvarlig for den huslige økonomi, og manden solder den blot op. "Ret hjælpen mod børnene, for de er samfundets fremtid". Og ikke mindst: "Giv råd snarere end penge". Rådgivning virker forebyggende, mens "død mønt" risikerer at have fordærvende virkninger. Filantropisterne fremhæver netop som deres styrke, at de er i stand til at yde en form for moralsk dannelse, som er det offentlige fattigvæsens materielle bistand langt overlegen. Således siger Vilhelm Munch, leder af Christianshavns Understøttelsesforening:

Fattigvæsenet kan slet intet gjøre for at holde deres farligste Fjender, Modløsheden og Sløvheden borte; vi vide af Erfaring, hvor meget stadige Besøg kunne hjælpe i saa Henseende, vide, at ofte er et opmuntrende Ord og en halv Times Samtale mere værd end en heel Deel Husleiehjælp og en heel Deel Brød (Munch 1867).

Samlet kan vi sige, at filantropisk fattighjælp har følgende karakteriska: den sætter skel mellem uvirksom materiel hjælp og virksom åndelig hjælp, hvorved den fattiges moralske konstitution kommer i centrum; den omdirigerer krav om forandring fra staten til den fattige familie og dens medlemmers livsførelse; den etablerer en skelnen mellem de viljesfyldte og de fortabte, som skal afgøre hjælpens karakter; og den søger at løse det liberale problem om, hvordan man reali- 
serer individuelle energier, præferencer og potentialer inden for et forpligtende fællesskab.

\section{Filantropiens genkomst}

Vi foretager nu et spring frem til starten af 1980'erne, hvor der sker en stadig mere udtalt genopdagelse af filantropiske principper i socialpolitikken og i det sociale arbejde. Samtidig ses et brud med den såkaldte "velfærdsplanlægning", som nåede sit højepunkt i 1960'erne og 1970'erne. Denne velfærdsplanlægning byggede på et forsikringsprincip, som den havde gjort bærende for sin universalistiske socialpolitik: sociale problemer blev anskuet som produkter af den kollektive orden, og staten blev gjort ansvarshavende for problemernes afhjælpning og kompensation. Klient-problemer blev fremstillet som fænomener, der kunne registreres objektivt - social funktionsdygtighed, modstandsevne, udsathed mv. og man søgte at opstille universelle definitioner på velfærd (Hänninen 1998). Klienterne blev konstrueret som rådvilde og forvirrede individer, der savnede overblik og ofte manglede erkendelse af deres hjælpe-behov. En central overvejelse var således, hvordan man kunne sikre, at alle borgere, der blev ramt af - eller bar en særlig risiko for at blive ramt af - sociale problemer, kom i kontakt med den offentlige fagekspertise. Velfærdsplanlægningen var båret af en stærk tiltro til, at når blot man udbyggede det sociale hjælpeapparat i tilstrækkeligt omfang og fik iværksat en tidlig, forebyggende indsats, så kunne man eliminere sociale problemer (Villadsen 2003a:153).

Det er hele denne planlægningsstrategi, der kommer under voldsom kritik i starten af 1980 'erne. For det første angribes statslig planlægning for at have en række ikke-intenderede og perverterende effekter. Angrebet betyder, at der opstår en række nye objekter for socialpolitikken og det sociale arbejde: lokale fællesskaber, netværk, frivillige organisationer mv. For det andet sker der en stadig voldsommere dekontruktion af velfærdsstatlige socialfaglige sandheder, der indebærer, at klientens selvforhold bliver socialpolitikkens egentlige mål. Begge bevægelser bringer paralleller frem til 1800-tallets filantropisk-liberale fattigpolitik. I det sociale arbejdes diskurs lyder en række filantropiske paroler nu fra alle sider: "man skal møde mennesket, som det er", "hjælp skal ydes som hjælp-til-selvhjælp" og "fattigdommen er åndelig, snarere end materiel". Der er naturligvis ikke tale om, at vi nu ser fortiden genopstå i nutiden i en identisk form. De filantropiske principper genindskrives i en specifik kontekst, hoor de fär nye strategiske funktioner. De indgår således i bevægelser, der forskyder ansvaret for løsning af sociale problemer, skaber nye talepositioner i det sociale arbejde og redefinerer centrale begreber som fællesskab, integration og frihed.

Først statskritikken og tiltroen til de lokale fællesskaber. Allerede i 1960'erne og op gennem 1970'erne havde der været en markant systemkritisk diskurs, der især blev fremført af socialarbejdere, venstreorienterede intellektuelle og forskellige frivillige organisationer. I denne diskurs blev "samfundet" eller "den materialistisk-kapitalitisk drevne samfundsudvikling" fremstillet som det egentige objekt for socialpolitik og socialt arbejde. Velfærdsplanlægningen blev anklaget for at individualisere sociale problemer, der i virkeligheden var et produkt af samfundets uhensigtsmæssige indretning. En indretning, der bl.a. krævede, at borgerne fortrængte deres naturlige kreative potentialer for at optræde som "producenter og konsumenter" i det accellererende og fremmedgørende industrisamfund. Samfundet hævdedes at have en interesse i at "uskadeliggøre" påfalden- 
de og kritiske personer ved at definere dem som afvigere. Overlæge i psykiatri Finn Jørgensen skrev fx:

(S)amfundet kan derved bevare sin gode samvittighed, idet det kan hævde, at disse mennesker ikke afviger på grund af konflikter i samfundets struktur, men fordi de primært er syge (Jørgensen 1968:175).

Der var i denne diskurs en tydelig reaktivering af Marx' begreb om mennesket som artsvæsen, som blev koblet med sociologiske begreber om stempling og stigmatisering hentet i Goffman-traditionen. Løsningen bestod i at udføre en form for socialt arbejde, der ikke reproducerede industrisamfundets logikker, men derimod medførte politisk bevidstgørelse. En sådan bevidstgørelse syntes kun at kunne finde sted inden for domæner, der var friholdt fra industrisamfundets påvirkninger og dominansstukturer. Derfor flyttede det kritiske sociale arbejde klienten ind i en type lokale fællesskaber, der var isoleret fra det omkringliggende samfund: det terapeutiske kollektiv, det politiske teater eller højskolen. Her hævdedes magten ikke længere at være til stede, og klient og socialarbejder kunne nu mødes i ligeværdighed og "finde ind til de mennesker, som de i virkeligheden var".

Den systemkritiske diskurs anvendte et sprog, som vi næppe kender i dag "tilpasningsteknikkere", "overlevelsespolitik", "psykostrissere", "solidarisk psykologi" - og den blev da også kraftigt udgrænset i slutningen af 1970'erne, bl.a. i takt med marxismens generelle miskreditering. Ét centralt element videreføres imidlertid i den stats- og proffessionskritik, som tordner frem i starten af 1980'erne, nemlig tiltroen til det lokale fællesskab. Socialminister Ritt Bjerregaard formulerer illustrativt statsforskræk- kelsen og eftersøgningen af de lokale fællesskaber i socialpolitikken:

Samfundsudviklingen har med-
ført opbrud i nogle tidligere fælles-
skaber, og det er ikke i særlig høj
grad lykkedes for os i socialsekto-
ren at bidrage til udviklingen af
nye fællesskaber. I stedet kan det
næsten tage sig ud, som om vi har
været med til at fremme isolation
og ensomhed. Jeg tænker her ikke
mindst på den måde, vi har op-
bygget vores institutioner på (Bjer-
regaard 1981:2).

Mens statsinstitutioner og professionelle socialarbejdere sættes lig med umyndiggørelse, passivisering og ansvarsovertagelse, hævdes de lokale fællesskaber med deres ildsjæle at rumme mulighed for udvikling af identitet, handlekraft og uafhængighed. Socialarbejdere må nu bistå klienterne med at opsøge de lokale fællesskaber, der konstrueres som problemløsende enheder. Der er her en betydelig nostalgi på spil: de lokale fællesskaber antages at have eksisteret engang eller at eksistere latent. Det er blot et spørgsmål om at bevidstgøre og genoplive dem. De lokale fællesskaber fremstilles også som mere "naturlige" og ægte end statsfællesskabet (Villadsen 2000). På denne måde er begrebet om lokale fællesskaber "taktisk polyvalent": Diskursen kan vendes mod dens oprindelige autoriteter. Hvad der startede som en systemkritisk diskurs og aktivist-strategi i 1970'ernes alternative sociale arbejde synes nu at blive en del af den statslige planlægning.

Alle er enige om, at der er sket en opløsning af de fællesskaber, som tidligere løste en række sociale problemer: landsbyen, naboerne, slægtninge og venner. Det er imidlertid ikke uproblematisk at aktivere de lokale enheders problemløs- 
ende ressourcer. Argumenterne om, at socialarbejderen præger borgeren i retning mod afhængighed, genspejles nemlig i identisk form i diskussionen om statens forhold til de lokale fællesskaber. Faktisk synes der, som Philp (1979:99) bemærker, at gælde de samme diskursive regler for artikulationen af relationen stat-civilsamfund, som der gælder for relationen socialarbejder-klient. I begge tilfælde drejer det sig om at intervenere med en sådan forsigtighed, at der værnes om de potentialer for uafhængighed og selvregulering, som hævdes at være såvel klienten som det lokale fællesskab iboende. De lokale fællesskaber kan altså næppe tilvejebringes gennem traditionel statslig styring. Ole Hermansen, rektor for Den Sociale Højskole i Århus, fremhæver netop behovet for, at græsrodsorganisationerne støttes på en sådan måde, at deres "egenart" bevares:

Det vanskelige for forvaltningerne bliver at bistå græsrodsorganisationerne på disses egne betingelser, uden at forvaltningerne falder tilbage i deres mere kendte kontrollerende rolle (Hermansen 1981:33).

Dilemmaet er, at socialpolitikkens succes i stigende grad afhænger af dens evne til at udvikle og opdyrke kræfterne i det civile samfund eller den såkaldt "tredje sektor". Samtidig skal denne sfære imidlertid bibeholdes som en ekstern og uafhængig modvægt til staten. Det civile samfund og dets aktører (frivillige organisationer, selvhjælpsgrupper, boligforeninger, lokale ildsjæle mv.) fremstilles som sårbare over for offentlig styring. En for nær og intensiv kontakt med statslige eller kommunale myndigheder antages at føre til en nedbrydning af den skrøbelige egenart, som kendetegner disse enheder. Socialpolitikken må derfor udvik- le metoder, der kan stimulere kræfterne uden for staten uden at styre eller "kolonisere" (Donzelot \& Estebe 2001). Det er i dette lys, vi skal forstå fremkomsten at diverse puljer, som skal stimulere lokale og frivillige inititativer uden at binde dem $i$ en permanent relation til det offentlige.

Den socialpolitiske strategi om at styre gennem lokale fællesskabers selvstyrende processer peger på, at "det sociale" forstået som statsfællesskab har vigende betydning som styringens referencepunkt (Rose 1996). Denne styringsstrategi søger at styre gennem de lokale fællesskaber ved at stimulere eller knytte an til disse fællesskabers selvstyrende processer. Men styringen må også "genopvække" eller aktivt søge at skabe et bestemt subjekt. Den sociale klient må begynde at betragte sig selv som del af lokale fællesskaber og sociale netværk. Hvis den marginaliserede skal udvikle identitet og tilbageerobre den myndighed, som det sociale apparat har frataget ham, må han indsættes i forpligtende fællesskaber, hedder det. Under overskriften "Fremtidens sociale arbejde skal starte $\mathrm{i}$ lokalmiljøet" skriver Karin Holland fx:

Afmægtigheden og den manglende indflydelse løses derfor ikke ved at fastholde klient-identiteten og satse på, at klientgruppen skal deltage aktivt i en organisation, de overhovedet ikke vil være medlem af [det sociale system, K.V.]. Men vi skal styrke klienterne til at de får identitet som lokalborgere og samfundsborgere og får indflydelse på eget liv, eget boligområde, i kommunalpolitik o.s.v. (Holland 1986:13).

I det sociale netværksarbejde fremhæves det, at klienten ikke blot skal være mere opsøgende i forhold til at få hjælp fra sit netværk; han skal også begynde at an- 
skue sig selv som en ressource for de andre personer i netværket. Den sociale klient må bringes til at genkende sig selv som del af et fællesskab, hvis medlemmers skæbne er forbundet i kraft af deres sociale problem, sygdom eller etniske baggrund. Borgeren skal med andre ord subjektiveres med reference til lokale fællesskaber og kulturer snarere end med reference til et overgribende statsfællesskab. Borgeren skal ikke længere subjektiveres primært som statsborger, men styres gennem hans følelse af samhørighed, hans erkendelse af fælles skæbne og hans forpligtelse over for sine nærmeste. Man må skabe "netværksbæreren"; et individ, der besidder en lokalt forankret subjektivitet (Villadsen et al. 1998:114).

De lokale fællesskaber fremstilles som domæner, hvor ligeværdig, umiddelbar solidaritet og genuin menneskelighed udfolder sig. Den socialpolitiske planlægning udgrænser på denne måde spørgsmålet om de lokale fællesskabers magtrelationer fra sin diskurs: magt synes altid at være noget, som udøves i relationen socialarbejder-klient, og ikke noget, der udøves i den frivillige organisation, $i$ den sociale café eller i selvhjælpsgruppen. Men det civile samfund er ikke magtfrit. Det rummer også sine dominansformer fx hustruvold, mobning, småracisme og lignende, som Kaare Nielsen (1993) påpeger. Det civile samfund og dets fællesskaber må derfor anskues som ambivalent. Det rummer på den ene side muligheden for en anderledes organisering af menneskelige relationer og for udvikling af alternativer former for socialt arbejde. På den anden side er det klart, at den kulturalistiske socialpolitiske strategi, der søger at styre gennem lokale fællesskabers selvberoende processer, også har sine magteffekter. Nye autoritetspositioner etableres, fx mellem den frivillige medarbejder i værestedet, der nu skal vurdere, hvornår "brugeren" er klar til at modtage et ud- dannelsestilbud, komme i afvænning eller bevæge sig fra at være bruger til at være frivillig. I dette lys er et oplagt spørgsmål, hvilke mekanismer der skal kontrollere det civile samfunds dominansrelationer, sikre lige adgang til ydelser mv., når socialpolitikken får til opgave at frisætte de lokale ressourcer?

\section{Klientens indre vilje}

Den anden bevægelse, der præger 1980' erne og 1990'ernes socialpolitik, er tendensen til, at klientens selvforhold kommer i centrum for indsatsen. Baggrunden er fortsat den kraftige kritik af, at dem, "der lever af at vide bedst", udøver ansvarsovertagelse og klientisering. $\mathrm{Nu}$ skal klientens magt over sig selv tilbageerobres, lyder det:

Klientiseret adfærd har bl.a. som
konsekvens, at ansvar for og magt
over eget liv skal tilbageerobres,
og den afhængige hjælpeløse ad-
færd skal aflæres (Vinther-Jensen
\& Lundemark Andersen 2000:474).

Det er i disse diskussioner vi mest tydeligt ser genopdagelsen af de filantropiske paroler.

For det første er der parolen om, at socialarbejderen skal "møde mennesket, som det er". Denne parole synes at radikalisere det dobbeltblik, som har præget det sociale arbejde siden 1800-tallets filantropi, nemlig iagttagelsen af klienten som på én gang partikulær og universel. Det fremhæves med stigende styrke, at man skal se klienten som det unikke individ, han er, uden forudfattede kategorier eller diagnoser. Man skal holde op med at kategorisere klienten og "møde mennesket, hvor det er", som det allerede formuleres i 1984 af Alkohol- og Narkotikarådets behandlingsudvalg (1984)4 . Op gennem 1980'erne og 1990'erne ses en stigende problematisering af den traditio- 
nelle socialfaglighed med dens objektive problembestemmelse og kategorisering af sine klienter. Problemet er, at socialarbejderen er tilbøjelig til at læse klientens udsagn og handlinger ind i sin egen forståelseshorisont i stedet for at se ham som det "hele" og unikke menneske, han rent faktisk er. I en artikel i Socialrådgiveren fra 1999 gør to socialrådgivere således op med det, de kalder et positivistisk og instrumentelt perspektiv i socialt arbejde:

\begin{abstract}
Den ansatte stræber efter "at se bagom" brugerens udsagn og søger at få et overblik over brugerens situation. Tolkningen opfattes typisk som neutral (...). Men det er den ansattes virkelighed, der bestemmer tolkningens indfaldsvinkler. Og målet er, at den ansatte kan skaffe sig et overblik på præmisser, som han/hun er fortrolig med (Buhl \& Flindt Pedersen 1999:18).
\end{abstract}

Forfatterne sætter skel mellem, på den ene side, en "abstrakt og positivistisk teo$\mathrm{ri}^{\prime \prime}$, der reducerer virkelighedens unikke mennesker, og, på den anden, en "etisk styret dialog", der er i stand til at se det hele menneske. I stedet for at oplyse, afdække eller forklare klientens situation hævdes den socialfaglige teori ligefrem at forvrænge og reducere virkeligheden. Især i eksperimenterende former for socialt arbejde betragtes de traditionelle socialfaglige discipliner som blokerende for, at man kan møde klienten, "som han er". Fx beskriver et projekt om empowerment i psykiatrien, hvordan både sygeplejen og socialrådgivningen tolker klientens udsagn ind i deres egen snævre faglighed:

De forskellige fagligheder kan i praksis være en hindring for at møde beboerne, hvor de er, lytte til det, de rent faktisk siger og inddrage dem mest muligt i egen behandling på egne præmisser (Vinther-Jensen \& Lundemark Andersen 2000:474).

Sideløbende med fremhævelsen af klienten som unik og partikulær, sker der på paradoksal vis en fortsat eftersøgning af klientens essentielle -og universelle - karakter. Faktisk synes det sociale arbejde i stigende grad at operere med et bestemt selv, som grundlæggende er ressourcefyldt, "positivt" og præferencebevidst, og opgaven bliver at bringe den enkelte $\mathrm{i}$ kontakt med dette selv. Alle klienter hævdes nemlig at rumme - hvad enten det er umiddelbart synligt for socialarbejderen eller ej - bestemte positive egenskaber, som man kan tale til. Det gælder fx ønsket om at være social, foretage visionær fremtidsplanlægning eller arbejde målrettet for at realisere personlige præferencer. I Revstedts omdiskuterede bog om motivationsarbejde tales der ligefrem om at "afdække den positive kerne" hos klienten (Revstedt 1995). Socialarbejderen må bistå klienten i at fjerne de "jeg-fremmede kræfter", således at han kan komme i kontakt med sin positive kerne-dvs. sit egentlige konstruktive jeg, som ligger gemt under psykoser, misbrug eller isolation. Belastede klienter er ofte stærkt afvisende. Men i stedet for at tage den afvisende attitude for pålydende skal socialarbejderen for sit indre øje bevare billedet af et angst og mistroisk mennesker, hvis adfærd i virkeligheden udtrykker et ønske om hjælp:

Motivationsarbejderen danner sig altid et billede af et menneske bag alle masker og spil. Motivationsarbejderen ser dette billede foran sig og reagerer på det, selvom klienten slet ikke forekommer at være sådan (Revstedt 1995:63). 
Denne forestilling om befrielse af klientens oprindelige karakter er til stede i mange forskellige typer socialt arbejde. I en instruktionsbog for aktiveringsprojekter og revalidering er målsætningen således at befri kontanthjælpsmodtageren fra den påførte afhængighedskultur og klientisering (Berg Sørensen 2001). Påstanden er, at klienten i udgangspunktet var besjælet af en lønmodtagerbevidsthed, men at denne er blevet fortrængt af et passiviserende socialt ydelsessystem. Aktivering skal "geninstallere" lønmodtagerindstillingen, således at klienten kan genindtræde i sin oprindelighed. $\mathrm{Og}$ i nogle tilfælde kan det endda være nødvendigt at anvende elementer af tvang for at bringe klienten i kontakt med sit egentlige jeg (Villadsen 2003b:203). Med denne befrielseslogik viderefører det sociale arbejde sin ældgamle dobbeltiagttagelse: der stilles på den ene side krav til socialarbejderen om at møde klienten som en unik størrelse. På den anden side synes socialarbejderen kun at kunne få øje på netop den iboende, universelle karakter, som han har konstrueret. Det er reaktiveringen af denne spænding, der tildeler det sociale arbejde sit fortsatte handlingsimperativ og muliggør dets evige tekniske kreativitet.

For det andet ser vi en genopdagelse af parolen "fattigdommen er åndelig snarere end materiel". Denne påstand sætter klientens selvforhold i centrum af det sociale arbejde, mens de materielle og "ydre" omstændigheder bliver sekundære. Parolen sætter skel mellem den virksomme åndelige hjælp og den uvirksomme materielle hjælp, som der hævdes at være blevet givet alt for meget af. Titlen på Karen Jespersens bog Opgør med den ny fattigdom skal netop signalere dette forhold. Vi slås stadig med skaderne af den passive forsørgelse, der blev et stort antal mennesker til del sidst i 1970'erne og op gennem 1980'erne, hævder hun. I stedet for rundhåndende ydelser må man indføre en "aktiv socialpolitik", der igangsætter modtagerne og bygger på forpligtelser (Jespersen 1999:37). Der må ydes en indsats, der ikke blot består i at sikre klientens materielle fornødenheder, men som altid sigter på at igangsætte en selvudvikling. Dette er forskellen mellem den passive og den aktive socialpolitik. Før klienten har fået styr på sig selv og sin selvforståelse, vil enhver materiel hjælp være spildt, lyder ræssonementet. Ofte viser det sig, at det egentlige problem, der forhindrer en positiv udvikling, er klientens selvopfattelse: klienten betragter sig selv som fastlåst, uden ressourcer, uden muligheder på arbejdsmarkedet osv.

Det bliver derfor klientens forståelse af sig selv, sine handlemuligheder og individuelle problemer, det drejer sig om at bearbejde - ikke ydre vilkår og samfundsbetingelser, der kunne hævdes at producere sociale problemer. Nøgleordet bliver altså igen selvværd. Det sociale arbejde konstruerer klienten som en person uden selvværd og myndighed over sig selv og lover at bibringe klienten denne myndighed (Cruikshank 1999). Hvis blot klienten er indehaver af selvværd, kan problemer lige fra langtidsarbejdsløshed til stofmisbrug overvindes. De nyeste opfindelser - "aktiv socialpolitik", "empowerment" og "myndiggørende socialt arbejde" - retter sig netop mod klientens selvværd. Vi kan også sige, at nutidens sociale arbejde retter sig mod selvets orden, ikke samfundets orden.

Hermed ses en tendens til, at klienten betragtes som en stadig mere fritstående størrelse, hvis adfærd og problemer i vigende grad tolkes som produkt af bagvedliggende strukturelle forhold (Howe 1996). Myndiggørende socialt arbejde drejer sig ikke om at læse klientens problemer ind i en større samfundsmæssig eller teoretisk model, men derimod om at 
opøve klientens evne til at formulere ønsker og visioner for sit liv (Nissen 1999: 243). Bekæmpelse af den åndelige fattigdom udgør derfor en særlig subjektiveringsstrategi, hvis mål er at fremelske en klient, der tænker sig selv som et $u d v i k$ lingsprojekt. Klientens iagttagelse af sig selv som fastlåst og styret af eksterne kræfter skal erstattes med en agttagelse af sig selv som mobil, indrestyret og ressourcefyldt. I dette projekt hævdes materiel hjælp i bedste fald at spille en underordnet rolle og i værste fald at være kontraproduktiv.

For det tredje er der parolen om "hjælp til selvhjælp". Denne problematiserer, i hvilket omfang det sociale arbejde faktisk kan være en hjælp. Parolen indskærper, at en for ivrig, generøs og dominerende hjælp vil blokere klientens selvrealisering. Den stiller spørgsmålet: hvornår er det klientens egen vilje, vi ser? Og hvornår er klientens adfærd udtryk for "tilpasning"? Hvordan kan vi vide, at klientens udtrykte ønsker ikke blot består i at snakke socialarbejderen efter munden? Som Anette Carstens skriver: "Tvungen vilje er ingen vilje. Det er bare tilpasning" (Carstens 1998:103) En succesfuld selvudvikling kræver, at det er klientens egne, indre præferencer og ønsker, der kommer til udtryk. Ellers vil indsatsen hverken være til gavn for klienten selv eller for samfundet. Parolen om hjælp til selvhjælp reaktiverer således et klassisk liberalt dilemma: en effektiv markedsøkonomi og et livskraftigt civilsamfund kræver, at den enkelte forfølger egne præferencer og udfolder egne potentialer. Men hvordan kan den enkelte realisere sig selv individuelt i forpligtelse på kollektivet?

Dilemmaet skaber således en spænding mellem autonomi kontra styring. Det tilbagevendende spørgsmål bliver, hvordan det sociale arbejde kan fremelske en klient-vilje, der kommer fra klien- ten selv, og ikke er blevet ham påduttet af socialarbejderen. Denne problematik afstedkommer en voldsom teknisk kreativitet i form af bl.a. kontrakter, nye former for motivationssamtale eller familierådgivning, hvor man beder familien om at tegne tegninger af deres ønsker for fremtiden (Fx Hougaard 1989). Altsammen for at sikre, at det er en genuin klientvilje, der realiseres. I opsøgende indsatser fremhæves det, at socialarbejderen aldrig må gå til den udstødte med bedrevidenhed og store planer, men i udgangspunktet skal nøjes med at "lege med fremtiden" i sin dialog med den enkelte udstødte. Den udstødtes ønsker for fremtiden skal bogstaveligt talt komme ud af hans egen mund. Her fx i projektet Basen på Københavns Hovedbanegård:
Når man har det dårligt, så er krav ikke lige det mest populære og det mest nemme at håndtere. Og der- for tror jeg, det er vigtigt, at man ligesom får leget med fremtiden. Det menneskes fremtid får man leget ind i det menneskes øre og bevidsthed. Igennem dets egen mund (Høgsbro 1992:42).

Påbuddet om at yde hjælp til selvhjælp skaber på denne måde en konstant mistænksomhed over for klientens udsagn: er de udtryk for en genuin, indre vilje eller et produkt af tilpasning?

Dilemmaet forstærkes af den postmodernistiske dekonstruktion, som præger det sociale arbejde. Socialarbejdere tager i stigende grad som udgangspunkt, at de traditionelle begreber om velfærd, integration, fællesskab, "det gode liv" osv. kan dekonstrueres. Der kan ikke gives klare svar på, hvad klienten skal integreres i, hvad han er produkt af, eller hvad der er velfærd for ham. Fra mange sider fremhæves, at socialt arbejde ikke kan udformes efter universelle principper, og 
at spørgsmålet om, hvad der er en god social indsats, aldrig kan fastslås endegyldigt. Sociallæge Preben Brandt skriver fx:

\begin{abstract}
Man kan ikke tilrettelægge socialt arbejde og socialpolitik sådan, at man kan slutte af med at sige, at nu har man gjort det rigtige og har endegyldigt indrettet samfundet godt og retfærdigt. (...) I denne sammenhæng er "rigtigt og forkert" ikke objektive eller indiskutable størrelser. Det må konstant debatteres på samme måde som normerne for, hvad der er det gode liv (Brandt 1999:14).
\end{abstract}

Hvad er godt, og hvad er ondt? Hvem er normal, og hvem er afvigende? Dette er skillelinier, som flyder og er relative i forhold til bestemte grupper, kulturer, tider og steder.

På den ande side har det sociale arbejde behov for at opretholde en substantiel forestilling om, hvad det frie menneske er, som man kan arbejde for at realisere. Denne spænding mellem konstruktivisme og essentialisme har indtil nu ikke passiviseret det sociale arbejde, men tværtimod afstedkommet en udvikling af nye metoder og arbejdsredkaber, der alle skal myndiggøre klientens egentlig selv. Den har heller ikke medført, at spørgsmålet om forpligtelser er gledet ud af det sociale arbejde. Der opereres stadig med forpligtelse, men det er en forpligtelse, der forbinder den enkelte til frllesskabet via hans selvforhold. Som klient er man ganske vist forpligtet til at deltage i bl.a. uddannelse, jobtræning eller aktivering. Men den mest grundlæggende forpligtelse er forpligtelsen til at arbejde med sig selv og sit selvforhold med henblik på at realisere iboende potentialer. På denne måde reaktiveres den moralske dimension i det sociale arbejde. Dagens socialarbejder må - ligesom filantropisten - sondre mellem dem, der fremviser vilje til selvbearbejdning og dem, hvor en sådan vilje ikke er synlig. Hjælp til selvhjælp kræver som bekendt, at der endnu er en vilje, der kan rejses.

\section{Nye begreber om medborger- skab, fællesskab og frihed}

Frisættelse drejede sig under velfærdsstatens opbygning om frisættelse fra materielle onder for at sætte borgeren i stand til at praktisere sit medborgerskab. I det kritiske sociale arbejde blev der formuleret en strategi om frisættelse fra det borgerlige samfund, dets undertrykkende ideologi og dets disciplinære institutioner. I nutidens sociale arbejde synes frisættelse først og fremmest at handle om tankens selvoverskridelse. Der sker en reaktivering af et filantropisk frihedsbegreb, som ikke drejer sig om at frisætte klienten fra strukturelle betingelser eller sociale vilkår, men om at frisætte hans indre vilje. Vi kan sige, at det nu drejer sig om at fremelske en klient, der nyder en ganske bestemt form for frihed, nemlig evnen til at overskride sig selv mentalt (Åkerstrøm Andersen 2003:120). En udviklingsorienteret selv-iagttagelse skal erstatte iagttagelsen af selvet som fastlåst, magtesløs og ydrestyret.

Genopdagelsen af filantropiske principper i det sociale arbejde og socialpolitikken ser således ud til at indebære, at centrale begreber i vores kollektive selvforståelse transformeres. Medborgerskabet får en mere moralsk forpligtende karakter, men således at arbejdet for at indløse egne potentialer via selvrefleksionens frihed bliver den egentlige forpligtelse. Fællesskabsforestillingen ændrer sig således, at vi i stigende grad skal integreres i lokalt forpligtende fællesskaber og fremelskes som lokalt orienterede subjekter. Og der synes at etablere sig et nyt frihedsbegreb, der indebærer, at frisæt- 
telse ikke handler om at frisætte fra materielle vilkår og påvikninger, men om en selv-refleksiv frihed - om at opøve evnen til at overskride sin egen mentale fastlåshed. Meget peger altså på, at der er ved at ske en opløsning af den socialfaglige diskurs, der med sine begreber om velfærdsstaten, "det sociale", almene behov, kollektive risici mv. har domineret det sociale arbejde i store dele af dette århundrede. I det lange perspektiv kan man således overveje, om den universalistiske og "alfavnende" velfærdsstat, der gennem mange år er blevet fremstillet som noget særligt skandinavisk og identitetsbærende, blot skal vise sig at blive en parentes i vores historie?

Det sociale arbejde hævder, at det bevæger mennesker i retning mod velfærd og lykke. Nogen gange argumenteres der for, at mennesket bringes tilbage til sin oprindelige, frie tilstand. Dette sker ved hjælp af skiftende videnskabelige og semi-videnskabelige teorier, der altid hævder at sætte sig ud over magt og politik for at i stedet levere effektive redskaber til at sikre menneskets velfærd og frihed. Genealogien viser imidlertid, at det sociale arbejdes mest moderne viden reaktiverer elementer fra historiske praksisser, der i nutidens øjne fremstår uoplyste, uvidenskabelige eller moraliserende. Frem for en ekspertdiskurs, der hviler på distinktionen sandt kontra falsk og taler om objektive problemer, modstandsdygtighed og evner, tales der i stigende grad inden for en moralsk diskurs, der hviler på distinktionen godt kontra ondt og opererer med begreber som følelse, forpligtelse og vilje. Det sociale arbejde beskæftiger sig ikke med videnskabelige, neutrale spørgsmål, men derimod med etisk-moralske problemer. Det vigtigste styringsobjekt i nutidens sociale arbejde er da også netop etisk-moralsk, nemlig klientens selvforhold.

De senere års neo-liberale kritik rum- mer med sin skepsis over for ekspertise og rationel planlægning en slags oplysningskritik. Den socialpolitiske planlægning baseret på ekspertviden er gået for vidt og kvæler nu de menneskelige potentialer, hedder det. Men midlet til at bekæmpe denne "oplysningens pervertering" er mere og bedre viden. Forhåbningen om, at vi for bestandigt kan overvinde fortidens uoplyste fejltagelser ved hjælp af videnskabelige-teknologiske løsninger (og hermed lægge spørgsmålet om forbindelsen mellem magt og viden bag os), må betragtes som endnu en diskursiv krigserklæring. I stedet må vi søge at vurdere omkostningerne ved at udgrænse én type viden til fordel for andre vidensformer - og herunder udgrænsningen af velfærdsstatens ekspertviden til fordel for filantropiske vidensformer.

\section{Noter}

Artiklen bygger på ph.d. afhandlingen Det sociale arbejdes genealogi - om kampen for at gøre fattige og udstødte til frie mennesker. Afhandlingen udkommer i en lettere omarbejdet form på Hans Reitzels Forlag i juni 2004.

1. Jeg ønsker at takke Esben Houborg Pedersen for grundige og frugtbare kommentarer til en tidlig version af denne artikel samt den anonyme referee for mange nyttige forslag.

2. Fængselsinspektør Frederik Stuckenberg skriver således: "Efter min erfaring er det Individ, som til sit 36te Aar har ført en ørkesløs og fordærvelig Tilværelse, i Almindelighed fortabt, selvom han flyttes bort fra det Samfund, han er kommet i Uoverensstemmelse med" (Stuckenberg 1869:36).

3. Strategien om at skabe foreninger for hjælp til selvhjælp er beskrevet i kapitel 6 i Det sociale arbejdes genealogi-kampen for at gøre fattige og udstødte til frie mennesker (under udgivelse).

4. Alkohol- og Narkotikarådets behandlingsudvalg formulerer dette synspunkt i rapporten At møde mennesket hoor det er i forbindelse med indførelsen af den såkaldte harmreduction-strategi: "For at få en svært belastet, socialt, fysisk og psykisk nedbrudt mål- 
gruppe i tale, er det af afgørende betydning, at man forsøger at møde klienten der, hvor han/hun befinder sig, og giver hjælpen et indhold, der opleves som meningsfuldt og rationelt af klienten. Konsekvensen heraf vil bl.a. være, at man må opgive det hidtidige krav om stoffrihed som betingelse for hjælp og i stedet forme tilbudene således, at de er på niveau med stofmisbrugernes umiddelbare behov" (Alkohol- og Narkotikarådets behandlingsudvalg 1984:131132).

\section{Litteratur}

Alkohol- og narkotikarådets behandlingsudvalg 1984: At møde mennesket hoor det er - om behandling af stofmisbrugere. København: Alkohol- og narkotikarådet.

Bang, Herman 1881: Herhjemme og Derude. Kjøbenhavn: J. H. Schubothes Boghandel.

Berg Sørensen, Torben 2001: Metodebog for projekter - aktivering og forrevalidering. Sociologisk Analyse, Risskov: Forlaget Gestus.

Bjerregaard, Ritt 1981: "Socialministerens tale". I: Socialministeriet 1981: Forsøg, eksperimenter, fornyelse, nytænkning - rapport fra forsøgskonference afholdt af Socialministeriet $i$ juni 1981. København: Cirkulærecentralen.

Brandt, Preben1999: Udelukkende velfxrd - debat om samfundet og de udstødte. København: Gyldendal.

Brodersen, Carl Wilhelm 1834: Armoden, dens Grund og dens Helbredelse - et Bidrag til formindskelsen af den overhaandtagende Forarmelse blandt den lavere Folkeklasse, Oversat af det Tydske ved J. W. Wolf. Kjøbenhavn: C. G. Schiellerup.

Bruun, L. et al. 1866: Beretning om Forhandlingerne paa det $i$ Kjøbenhavn den 24de og 25de October 1865 afholdte Møde til Discussion af Spørgsmaal vedkommende de fattige Samfundsclassers Vel. Kjøbenhavn: Jacob Lunds Boghandel.
Buhl, Jesper \& Flindt Pedersen, Jane 1999: “Den ægte dialog". I: Socialrådgiveren, nr. 18, 11. september, 1999.

Carstens, Anette1998: Aktivering - klientsamtaler og socialpolitik. København: Hans Reitzels Forlag.

Cruikshank, Barbara 1999: The Will to Empower - democratic citizens and other subjects. Ithaca: Cornell University Press.

Donzelot, Jacques 1979: The Policing of Families. New York: Pantheon Books.

Donzelot, J. \& Estebe, P. 2001: "Staten som igangsætter - et essay om bypolitik. I: Greve, A. (red.) 2001: Sociologien om velfærd-gensyn med Émile Durkheim. Roskilde: Roskilde Universitetsforlag.

Durkheim, Émile 2000: Om den sociale arbejdsdeling. København: Hans Reitzels Forlag (opr. 1902/1930).

Elias, Nobert 1994: The Civilizing Process. Oxford: Blackwell (opr. 1939).

Foucault, Michel 1991: "Questions of Method". I: Burchell, G. et al (red) 1991: The Foucault Effect. Hemel Hemstead: The University of Chicago Press.

Hermansen, Ole F. 1981: "Socialforvaltningernes opbyggende sammenspil med de lokale fællesskaber". I: Socialpolitisk forening 1981, Kommunernes socialpolitik ved en korsvej - udvikling eller konflikt, Socialpolitisk forenings småskrifter 55, København: Socialpolitisk forening.

Hoff, V. J. 1881: Hjemmet. Kjøbenhavn: Karl Schønbergs Forlag.

Holland, Karin 1986: "Fremtidens sociale arbejde skal starte i lokalmiljøet" . I: Socialrådgiveren, nr. 24, 1986.

Hougaard, Bent 1989: Hjemme er bedst grundprincipper i forældreuddannelse og familieudvikling. Vejle: ISU.

Howe, David 1996: "Surface and depth in social-work practice". I: Parton, N. 1996: Social Theory, Social Change and Social Work. London: Routhledge. 
Høgsbro, Kjeld 1992: Basen - et opsøgende socialt arbejde på Hovedbanegården. Kobenhavn: Casa.

Hänninen, Sakari 1998: "Is Finland going beyond the age of entitlement?". I: Hänninen, S. (red) 1998: Displacement of social policies, Publications of Social and Political Sciences and Philosophy 19, Jyväskylä: University of Jyväskylä.

Jespersen, Karen 1999: Opgør med den ny fattigdom. Viborg: L \& R Fakta.

Johansen, K. 1883: Om Opdragelsen og dens særlige Forhold til Filantropi og Hygiejne. Kjøbenhavn: Karl Schønbergs Forlag.

Jørgensen, Finn 1968: “Bør socialarbejderne være instrumenter for tilpasning til det bestående samfund?" I: Socialrådgiveren, 30. årgang, oktober 1968.

Kaare Nielsen, Henrik 1993: "Det ambivalente civilsamfund". I: Social Kritik nr. 29, 1993.

Munck, Vilhelm et al. 1867: Om de Fattiges Vilkaar paa Christianshavn. Kjøbenhavn: Den Gyldendalske Boghandel.

Nissen, Morten 2000: Projekt Gadebørn Et forsøg med dialogisk, bevægelig og lokalkulturel socialpxdagogik med de mest udsatte unge. Frederikshavn: Dafolo Forlag.

Philp, Mark 1979: "Notes on the form of knowledge in social work". I: The Sociological Review, volume 27, no. 1, 1979.

Revstedt, Per 1995: Ingen er håbløs - motivationsarbejde i teori og praksis. København: Hans Reitzels Forlag.

Rose, Nicolas 1996: "The Death of the Social? Refiguring the territory of government". I: Economy and Society, volume 25, number 3, August 1996.

Sandberg, Ole 1869: Om Fattigdommen Foredrag holdte paa Sagatun Folkehøjskole. Christiania: J.W. Cappelens Forlag.
Stuckenberg, Frederik 1869: Fattigdom og Fattigforsorg. Kjøbenhavn: Jacob Lunds Forlag.

Villadsen, Kaspar 2003a: Det sociale arbejdes genealogi-om kampen for at gøre fattige og udstødte til frie mennesker. Ph.d. afhandling, København: Sociologisk Institut, Københavns Universitet.

Villadsen, Kaspar 2003b: "Det sociale arbejde som befrielse". I: Järvinen, M. \& Mik-Meyer, N. 2003: At skabe en klient. København: Hans Reitzels Forlag.

Villadsen, Kaspar 2002: “Foucault og liberalismekritik - governmentality eller genealogi som analysestrategi“. I: Dansk Sociologi, nr. 3, 2002.

Villadsen, Kaspar 2000: "Frivillige organisationers rolle på alkohol- og narkotikaområdet - rummer disse organisationer en særlig rationalitet og særlige arbejdsmetoder?" I: Sosiologisk Tidsskrift, Årgang 8, nr. 3, 2000.

Villadsen, Kaspar et al. 1998: Socialpolitiske strategier - på tværs af sektorer og organisationer. København: Socialforskningsinstituttet.

Vinther-Jensen, Kirsten \& Lundemark Andersen, Maja 2000: "Empowerment i psykiatrien". I: Halling-Overgaard, P. \& Uggerhøj, L. (red) 2000: En samling papers fra tredje nordiske symposium - samspillet mellem praksis og forskning $i$ socialt arbejde, 4.- 6. november, Århus.

Åkerstrøm Andersen, Niels 2003: Borgerens kontraktliggørelse. København: Hans Reitzels Forlag.

Weber, Max 1995: Den protestantiske etik og kapitalismens ånd, København: Nansensgade Antikvariat, (opr. 1920). 